\title{
Perbedaan Budaya dan Adaptasi Antarbudaya dalam Relasi Kemitraan Inti-Plasma
}

\author{
MC Ninik Sri Rejeki ${ }^{1}$
}

Abstract: The difference of culture is a primary characteristic of the intercultural communication. Cultural difference implies to the different communication behavior. These differences raise various communication problems in which its solution needs certain communication competence. Cultural difference in estate system in Indonesia was started by dualistic economy reality and it turns to the raise of the cultural dualism. In one side big estate is oriented to modern capitalism (nucleus estate), and another side small holders (plasma farmer) is oriented to the traditional pre-capitalism. They develop intercultural communication competence by establishing strategy of convergent and divergent adaptation. The difference between nucleus estate and plasma farmer is based on the differences of existence in the orientation of farming and structural tightness. The communities of nucleus estate have culture that take root in economic interests (commercial). Meanwhile some of farmer communities are oriented to family and the communities' interest. Standardization of existence and control towards job is a part of structural tightness

MC Ninik Sri Rejeki adalah staf pengajar pada Program Studi Ilmu Komunikasi, FISIP, Universitas Atma Jaya Yogyakarta 
characteristic and nucleus estate's masculinity. However there are a few modern farmers that begin to concern to the business. This study also shows the adaptation strategy in the communication behavior is applied by nucleus estate people. Adaptation strategy is divided into two strategies: (1) convergent strategy manifested by the adjustment in other party's communication behavior, meanwhile the divergent strategy manifested by the show of the different behavior appearance as their culture identity.

Key words: Cultural difference, intercultural adaptation, communication competence, convergence, divergence

Dalam tataran teoritik, komunikasi merupakan fungsi dari budaya dan perilaku komunikasi seseorang merupakan cerminan dari budayanya itu. Namun dalam tataran praksis, karena komunikasi bersifat simbolik, maka ketika seseorang menggunakan simbol sering mengasumsikan orang lain juga menggunakan sistem simbol yang sama. Hal ini menjadi bermasalah ketika komunikasi itu dilakukan dengan pasangan yang memiliki budaya dan sistem simbol berbeda. Masalah yang sering timbul adalah terjadinya perbedaan persepsi atas pesan yang disampaikan oleh komunikan, sehingga komunikasi tidak dapat mencapai tujuannya. Masalah tersebut bisa dipecahkan bila seseorang memiliki kompetensi tertentu, salah satunya adalah adaptasi antarbudaya.

Apabila dicermati kajian tentang adaptasi yang ada, umumnya masih berkisar dalam konteks akulturasi sosial para migran (sojourner adjusment). Muncul pertanyaan, bagaimana adaptasi akan terjadi bila anggota komunikator adalah kelompok sosiologis, bukan antarbangsa. Kajian adaptasi dalam konteks komunikasi antarkelompok sosiologis sangat relevan dalam proses pembangunan saat ini, terutama mengingat kemanfaatannya untuk mengembangkan sistem penyuluhan pembangunan.

Proses penyuluhan pembangunan, acapkali mengalami kekurangberhasilan hanya disebabkan oleh adanya hambatan perbedaan budaya di antara kelompok sosiologis. Salah satu contoh ketidakberhasilan itu adalah 
yang terjadi di dalam hubungan kemitraan antara perkebunan besar dan petani kecil. Perkebunan besar dan petani kecil merupakan dua kelompok sosiologis yang memiliki karakterististik sangat berbeda. Perbedaan ini merupakan realitas dari kehidupan ekonomi dualistik dalam sistem perkebunan di Indonesia. Kelompok yang satu berorientasi pada kapitalisme modern, sementara kelompok lainnya berciri pra kapitalisme tradisional.

Munculnya sistem pembangunan perkebunan dengan pola Perkebunan Inti-Rakyat (PIR) pada tahun 1978/1979, merupakan upaya memadukan perkebunan besar dengan petani kecil dalam suatu proses produksi dengan analogi hubungan inti-plasma. Dalam perkembangannya, bentuk relasi kedua pihak tersebut adalah berupa relasi kemitraan antara perusahaan inti dan petani plasma. Kemitraan dirumuskan sebagai relasi kolaborasi antara dua pihak atau lebih yang dilakukan dalam sistem yang utuh untuk mencapai keuntungan bersama. Menurut Martodireso \& Widodo (2002:11), relasi kemitraan dalam usaha pertanian harus didasari oleh sikap saling percaya, saling membutuhkan, saling menguntungkan, dan saling memperkuat. Dalam relasi kemitraan, harus ada proses pembinaan dan pengembangan yang berkelanjutan dari pengusaha besar terhadap mitranya yang tergolong pengusaha kecil (Sumardjo, 2004:16).

Martodireso \& Widodo (2002:17), mengungkapkan perlunya para pelaku kemitraan membangun relasi sosial yang baik, seperti komunikasi interaktif, saling memberdayakan, dan tidak saling memaksa. Menurut Suroso(1994:14), dalam perkembangannya, ada masalah yang menghambat harmoni relasi tersebut. Relasi antara perusahaan inti dan petani plasma kurang harmonis karena perbedaan pola pikir, sikap, dan perilaku yang memunculkan masalah operasional. Ini menunjukkan bahwa komunikasi sebagai aktivitas simbolik tidak diikuti oleh keakuratan persepsi atas pesan kedua belah pihak. Ketidakakuratan persepsi ini disebabkan karena perusahaan inti dan petani plasma adalah dua komunitas yang memiliki perbedaan budaya.

Wacana kemitraan dalam pembangunan sistem perkebunan di Indonesia dapat dipandang sebagai suatu peristiwa komunikasi. Dalam perspektifkomunikasi, berbagaimasalah dalamkemitraan antaraperusahaan inti dan petani plasma menunjukkan adanya masalah komunikasi yang disebabkan karena perbedaan budaya kedua pihak. Realitas empirik adanya ketidaksesuaian perilaku dalam praksis kemitraan menunjukkan 
upaya mengubah perilaku melalui penyuluhan menjadi permasalahan serius. Dalam perspektif komunikasi antarbudaya, permasalahan ini membutuhkan kompetensi komunikasi yang memungkinkan tujuan komunikasi tercapai. Adaptasi dalam kerangka ini merupakan kompetensi komunikasi untuk mencapai perubahan perilaku petani. Tulisan ini bertolak dari penelitian dengan rumusan masalah (1) Bagaimanakah budaya komunitas perusahan inti dan komunitas petani plasma? (2) Adakah perbedaan perilaku komunikasi sebagai implikasi dari perbedaan budaya itu? Tujuan penelitiannya adalah memahami adaptasi antarbudaya di antara dua komunitas tersebut.

\section{METODE PENELITIAN}

Penelitian yang dilakukan menggunakan paradigma konstruktivisme dengan perspektif teoritik fenomenologi. Tipe dan metode penelitian yang digunakan penelitian kualitatif. Sebagai studi kualitatif, pengumpulan dan analisis data bersifat nonkuantitatif, yaitu teknik wawancara mendalam dan analisis data kualitatif. Sementara itu, tujuan penelitiannya adalah mengeksplorasi relasi sosial yang membentuk bangunan komunikasi antarbudaya. Subyek penelitian adalah individu dari komunitas perusahaan inti dan komunitas petani plasma. Penelitian dilakukan di wilayah Pabrik Teh Kaliboja, Pekalongan, yaitu salah satu dari tiga unit produksi Perusahaan Teh PT Pagilaran. Alasannya bahwa unit ini merupakan unit pertama yang menerapkan pola PIR, sehingga banyak problema yang pemecahannya memerlukan kompetensi komunikasi.

Teknik pengumpulan menggunakan indepth-interview. Instrumen yang dipakai dalam rangka penggunaan teknik ini adalah diri peneliti sendiri dengan alat bantu berupa interview guide atau panduan wawancara. Wawancara mendalam dilakukan pada sejumlah informan. Pendalaman informasi dilakukan sesuai kebutuhan untuk menjawab masalah penelitian. Teknik pengolahan data dengan mengembangkan sistem koding berasal dari kisah responden, pertanyaan penelitian, dan kerangka teroritik. Analisis dilakukan dalam tiga tahap, yaitu tahap eksplanasi peneliti terhadap fenomena yang berbekal ilmunya (etik), tahap sinkronisasi antara pandangan emik dan etik, dan tahap rasionalisasi serta abstraksi data. 
Ada berbagai topik kajian dalam kawasan studi komunikasi antarbudaya. Topik itu menyangkut aspek identitas kultural, adaptasi dalam proses komunikasi antarbudaya, konflik antarbudaya, dan sebagainya. Sebagai salah satu topik kajian dalam komunikasi antarbudaya, adaptasi adalah suatu problema yang perlu dipecahkan ketika seseorang atau kelompok orang berkomunikasi dengan pihak lain yang berbeda budaya.

Adaptasidalamkawasanstudikomunikasiantarbudayapadaumumnya dikaitkan dengan perubahan dari masyarakat atau bagian dari masyarakat. Adaptasi adalah salah satu orientasi pembelajaran interkultural. Orientasi adaptif terdiri dari mencari dan memberi perhatian pada lingkungan. Seseorang yang memilih strategi adaptif cenderung memiliki kesadaran yang tinggi terhadap harapan dan tuntutan dari lingkungannya, sehingga siap untuk mengubah perilaku. Orientasi ini menyebabkan seseorang untuk fleksibel dan diplomatis.

\section{Teori Adaptasi Antarbudaya}

Adaptasi antarbudaya merupakan suatu proses panjang penyesuaian diri untuk memperoleh 'kenyamanan berada dalam suatu lingkungan yang baru. Dalam "Intercultural Communication Theories", Gudykunst (2002:183) memaparkan bahwa teori adaptasi budaya termasuk ke dalam kelompok teori akomodasi dan adaptasi. Salah satu teori yang dikemukakan dalam paparan itu adalah teori adaptasi antarbudaya dari Ellingsworth.

Ellingsworth (1988: 271) mengemukakan, perilaku adaptasi dalam interkultural diadik terkait antara lain dengan unsur adaptasi dalam gaya komunikasi. Gaya adalah tingkah laku atau perilaku komunikasi. Menurut Gudykunst dan Kim (1997:337), adaptasi dapat terjadi dalam dimensi kognitif. Dalam dimensi kognitif, terjadi penyesuaian bahasa verbal dan nonverbal. Oleh karena itu dapat dikatakan bahwa adaptasi dapat terjadi dalam dimensi perseptual, kognitif, dan perilaku.

Teori yang berfokus pada akomodasi dan adaptasi lainnya dikemukakan Gile. Teorinya disebut teori akomodasi komunikasi atau communication accomodation theory (CAT). Teori ini bertolak dari teori akomodasi percakapan. Menurut teori ini, pembicara menggunakan strategi linguistik untuk mencapai persetujuan atau untuk menunjukkan perbedaan dalam interaksinya dengan orang lain. Strategi komunikator 
yang utama adalah berdasarkan pada motivasi divergensi dan konvergensi. Perpindahan linguistik ini untuk meningkatkan dan mengurangi jarak komunikasi. Sikap setuju dinyatakan dengan konvergensi. Sementara itu divergensi dilakukan sebagai pernyataan menolak (Gudykunst, 2002:187).

\section{Dimensi Keragaman Kultural untuk Mengkaji Perbedaan Budaya}

Perbedaanbudaya diantara komunitas perusahaan inti dan komunitas petani plasma dijelaskan dengan bertolak dari adanya pergulatan di antara dua prinsip yang disebut sebagai perekonomian dualistik. Pergulatan ini berakar dari pertentangan antara kapitalisme barat yang modern dan tradisi pra-kapitalis. Kapitalisme barat yang modern, muda, dan agresif yang dibangun di kota besar berhadapan dengan tradisi pra-kapitalis yang tua yang berada di pedesaan (Boeke, 1983:11).

Menurut Boeke (1983:11), dalam situasi dualistik terdapat dua karakteristik yang berbeda dalam konteks sosial ekonomi. Satu sisi merupakan golongan masyarakat yang memiliki ikatan sosial asli dan organis, sistem kesukuan tradisional, kebutuhan yang sifatnya terbatas dan bersahaja, serta prinsip produksi pertanian yang sifatnya subsisten. Sisi lainnya adalah masyarakat yang berorientasi keuntungan, bersaing usaha yang terorganisasikan, profesional, bertumpu pada kapitalisasi dan industri mekanis, serta memandang rendah dorongan atau motif ekonomi yang dikaitkan dengan motif sosial, etika, adat, tradisi, suku, agama, dan sebagainya. Dalam kehidupan pertanian, kapitalisme diasosiasikan dengan farmer yang berciri kota, sementara prakapitalisme diasosiasikan dengan peasant yang berciri desa.

Dalam kerangka ini peasant merupakan masyarakat yang (1) hidup dari mengolah tanah, (2) hidup menetap dalam komunitas pedesaan, (3) menggunakan teknologi pertanian, seperti pacul, bajak, dan garu untuk melakukan produksi pertanian, (4) memiliki hubungan dengan kota. Selain itu juga mengolah tanah untuk tujuan subsistensi.

Kroeber dalam Foster (1967:2) mengemukakan bahwa peasant merupakan bagian masyarakat dari suatu budaya yang hidup dalam kaitannya dengan pasar dan pusat kota. Golongan masyarakat ini tidak lagi terisolasi, namun masih memegang nilai tradisional. Sementara itu menurut Firth (Marzali, 1998:85), sistem ekonomi peasant adalah 
sistem ekonomi yang menggunakan ketrampilan dan pembagian kerja sederhana, memiliki keterbatasan akses ke pasar, alat produksi dikuasai dan diorganisasikan secara nonkapitalistik, skala produsen tergolong kecil dengan hubungan produksi bersifat lebih personal, dan perhatian terhadap aspek sosial dan keagamaan lebih diutamakan daripada aspek materi. Menurut Wolf (1983:2), peasant merupakan orang desa yang bercocok tanam dan berternak di daerah pedesaan. Usaha tani tersebut tidak dilakukannya sebagai petani farmer atau pengusaha pertanian (agricultural enterpreneur) karena tidak dilakukan sebagai kegiatan bisnis untuk meraih keuntungan ekonomis, namun dilakukan dalam kerangka pengelolaan rumah tangga.

Dalam melakukan produksi pertanian, peasant harus mengarahkan kegiatannya untuk melayani keluarga dan masyarakat. Hal ini sebagaimana dikemukakan oleh Diaz (1967:50), yaitu bahwa peasant sebagai man economic harus mengarahkan aktivitasnya dalam dua ruang, yakni ruang keluarga dan ruang masyarakat. Perhatian peasant terhadap keluarga dan masyarakatnya dikemukakan pula oleh Popkins (1979:28), yaitu bahwa pihak-pihak yang menjadi perhatian utama peasant adalah diri sendiri, keluarga, tetangga, dan komunitas desanya. Didalamruangkeluarga maupun ruang masyarakat, peasant memberi dukungan dengan produksi usaha tani yang dilakukan dalam kondisi kesederhanaannya dengan teknologi non-industri dan bertumpu pada rumah tangga (household based), serta produksi pertanian berorientasi subsistensi (Elson, 1997:xix). Menurut Scott (1981:7), usaha subsistensi adalah usaha tani yang mengutamakan keamanan (safety first). Dalam kehidupan tertib sosial masyarakat, peasant perlu selalu menjaga relasi antarrumah tangga dan memelihara keseimbangan antara kepentingan keluarga dan masyarakat yang dapat mengikat peasant dengan masyarakat yang lebih luas. Menurut Wolf (1983:170), dalam kerangka ini upacara atau ritual memiliki suatu fungsi melegetimasi unit sosial dan relasi di antara sesama warga desa. Selain itu dari sudut komunikasi sosial, hal ini dapat mengukuhkan eksistensi peasant dalam komunitasnya. Sebagai produsen pertanian berskala kecil, tindakan dan pilihan petani selalu dikaitkan dengan sumber daya alam, seperti tanah, air, iklim, dan matahari. Dengan demikian peasant memiliki hubungan yang kuat dengan sistem ekologis (Weizt (1971:19). Kuatnya pertalian peasant dengan kondisi ekologis menciptakan pula prosedur 


\section{Jurnal}

dalam melakukan usaha tani. Keadaan ini menyebabkan petani akan sangat berhati-hati dalam menerima introduksi teknologi baru. Dalam pandangan peasant, perubahan teknologi sekecil apapun akan membawa pada konsekuensi yang tidak terantisipasi yang dapat mengancam sistem produksi pertanian (Weitz, 1971:9).

Dalam menerima teknologi baru yang berimplikasi adanya prosedur yang berbeda dengan kebiasaan bertani, petani menggunakan pola pikir safety first demi keamanan subsistensinya. Analisis Scott (1981:3) menemukan bahwa etika subsistensi di kalangan petani Asia Tenggara merupakan akibat dari kehidupan petani yang dekat dengan garis batas yang merupakan garis antara keamanan dan risiko Oleh karena itu dapat dikemukakan bahwa dalam perspektif moral ekonomi petani, peasant merupakan golongan petani yang selalu menentang risiko.

Soekartawi (2003:173) mengemukakan bahwa agribisnis terdiri dari petani yang selalu melakukan upaya memaksimalkan pendapatan dengan penguasaan sumber daya yang terbatas. Adapun cirinya, pertama, cepat mengadopsi inovasi sehingga digolongkan sebagai pengadopsi awal (early adopters). Kedua, memiliki derajat kosmopolitan yang tinggi. Ketiga, memiliki keberanian menanggung risiko dalam berusaha tani. Keempat, memiliki sikap mau dan kemampuan mencoba teknologi baru yang ditunjang oleh sumber daya yang memadai. Slamet (2003:16) mengemukakan bahwa untuk peningkatan produksi dalam pembangunan pertanian diperlukan teknologi maju. Oleh karena itu petani perlu mengadopsi teknologi maju. Dalam perspektif penyuluhan pembangunan, petani maju adalah petani yang memiliki kemampuan untuk memerankan diri sebagai warga negara yang baik sesuai dengan profesinya, dan sanggup berswadaya untuk meningkatkan kesejahteraannya sendiri dan masyarakatnya (Slamet, 2003:18).

Pambudy (2003:235) mengemukakan bahwa seorang usahawan agribisnis merupakan orang yang mampu untuk menyelesaikan proses dari menghasilkan ide kreatif, inovasi, hingga menghasilkan produk barang atau jasa untuk dapat dipasarkan dengan keuntungan yang memadai. Selain sebagai petani komersial berbudaya industri, farmer juga dapat digolongkan sebagai petani modern. Menurut Suriasumantri (2000:384), masyarakat modern yang urban memiliki indikator sebagai berikut, pertama, bersifat analitik. Di samping itu, sebagian besar aspek kehidupannya 
dilandaskan pada asas efisiensi secara teknis maupun ekonomis. Indikator ini menempatkan nilai teori dan nilai ekonomi pada posisi penting. Nilai teori terkait dengan aspek penalaran, ilmu, dan teknologi, sedangkan nilai ekonomi berpusat pada penggunaan sumber dan benda ekonomi secara efektif dan efisien berlandaskan perhitungan yang bertanggung jawab. Sementara itu pengambilan keputusan berlandas pada argumentasi kuat. Kekuatan berpikir bersifat dominan yang mengabaikan penarikan kesimpulan dari intuisi, perasaan, dan tradisi. Kedua, bersifat individual. Nilai sosial dan kekuasaan dalam kerangka ini harus berorientasi pada kepercayaan diri sendiri serta keberanian untuk mengambil keputusan sendiri. Hubungan antarmanusia bersifat individual, sementara untuk mempertahankan hidup seseorang harus mampu bersaing secara produktif. Perbedaan budaya lainnya dari peasant dan farmer lainnya dapat dikaitkan dengan dikotomi budaya yang dapat dijelaskan dengan konsep orientasi nilai dari Kluckhohn dan Strodtbeck, individualisme-kolektivisme, variabilitas budaya Hofstede, Pola-pola Parsons, dan keketatan Struktral.

\section{Orientasi Nilai dari Kluckhohn-Strodtbeck}

Kluckhohn-Strodtbeck memunculkan dimensi orientasi nilai. Dimensi ini terdiri dari orientasi sifat manusia, orientasi sifat orang, oientasi waktu, aktivitas, dan orientasi relasional (Gudykunst dan Kim, 1997:78). Dimensi pertama adalah orientasi sifat manusia yang terkait dengan sifat bawaan. Dalam dimensi ini, manusia dipandang baik atau jahat atau campuran antara baik dan jahat yang merupakan pembawaan sejak lahir. Dimensi kedua, orientasi relasi manusia dan alam. Ada tiga jenis relasi, yaitu takluk, menyelaraskan, dan mengendalikan. Dimensi ketiga, orientasi waktu. Dalam dimensi ini, kehidupan manusia dapat berfokus pada masa lalu, masa kini, atau, masa depan. Orientasi yang kuat terhadap masa lalu cenderung menonjol pada kelompok budaya yang menempatkan tradisi dalam posisi yang utama, seperti pemujaan pada leluhur atau yang memberi tekanan lebih pada kohesivitas keluarga. Dimensi keempat, orientasi aktivitas. Menurut Kluckhon-Strodtbeck, orientasi aktivitas dapat dipandang sebagai doing, being, dan being-in-becoming. Orientasi doing berfokus pada jenis aktivitas yang memiliki keluaran eksternal yang dapat diukur. Oleh karena itu aktivitas ini harus nyata. Dalam kerangka ini terdapat pula orientasi pada capaian hasil. Dimensi kelima, orientasi relasional. 
Orientasi relasional terkait dengan dimensi individualisme-kolektivisme. Keterkaitan itu adalah karena cara orang berinteraksi memiliki fokus yang berbeda, yaitu ke arah individualisme atau kolektivisme.

\section{Individualisme-Kolektivisme}

Menurut Hui dan Triandis (Triandis, 1995:31), dalam budaya kolektivistik, para anggota kelompok budaya sangat rentan terhadap pengaruh sosial karena adanya gagasan interdependensi, memberi perhatian pada penyelamatan muka dan integritas keluarga, serta menggunakan bersama hasil yang mereka raih di dalam kelompoknya. Selain itu juga menekankan ide pentingnya pengembangan kemampuan berhubungan sosial.

Gudykunst dan Lee (2002:27) mengemukakan bahwa di dalam individualisme terdapat kecenderungan untuk menempatkan identitas individu di atas identitas kelompok. Dalam kerangka ini, tujuan dan hak individu memiliki tempat di atas tujuan dan hak kelompok. Demikian pula dengan kebutuhan individu yang menempati posisi di atas kebutuhan kelompok. Hofstede (1994:50) berpendapat bahwa dalam masyarakat kolektivis, kepentingan kelompok berlaku di atas kepentingan individu. Kelompok (in-group) merupakan sumber identitas seseorang dan para anggota kelompok akan memandang diri sebagai 'kami'. Kelompok menjadi tempat berlindung bagi anggota pada saat menghadapi kesulitan hidup. Oleh karena itu para anggota akan senantiasa setia pada kelompok. Ketidaksetiaan dengan demikian adalah suatu perilaku yang dipandang buruk. Di sisi lain, masyarakat individualis akan menempatkan kepentingan individu di atas kepentingan kelompok. Anggota kelompok memandang diri sebagai "aku".

Pada masyarakat kolektivistik, individu dilahirkan dalam integrasinya dengan in-group, disertai dengan kohesi sosial yang kuat, antara lain ditunjukkan dengan adanya saling perlindungan di antara anggota ingroup, serta adanya pertukaran kesetiaan yang bersifat taken for granted. (Gudykunst dan Kim, 1997:56). Menurut Triandis, pengaruh in-group dalam budaya individualistik sangat spesifik, sedangkan ruang pengaruh in-group dalam budaya kolektivistik bersifat umum, sehingga para anggota budaya individualistik cenderung bersikap universalistik dan menggunakan standar nilai sama bagi setiap orang. Sebaliknya, para anggota budaya 
kolektivistik cenderung partikularistik dan menggunakan standar nilai berbeda untuk para anggota in-group dan out-group (Gudykunst dan Lee, 2002:27).

\section{Variabilitas Budaya Hofstede}

Menurut Hofstede (1994:109), ketidakpastian dirasakan dan dipelajari oleh seorang anggota budaya dari warisan budaya yang dipindahkan serta digerakkan melalui institusi dasar, seperti keluarga dan sekolah. Perasaan itu direfleksikan ke dalam nilai yang dipegang secara kolektif oleh anggota masyarakat, serta kemudian menuntun pola perilaku kolektif suatu masyarakat yang tidak mudah dipahami oleh masyarakat lainnya.

Para anggota budaya yang berderajat tinggi dalam menghindari ketidakpastian memiliki toleransi yang rendah pada ketidakpastian dan sesuatu yang sifatnya ambigu. Para anggota dari kelompok budaya ini juga memiliki kebutuhan yang besar akan adanya peraturan formal dan kebenaran mutlak. Selain itu juga kurang memberi toleransi pada ide atau perilaku yang menyimpang dari peraturan formal. Sementara itu, orang dari kelompok budaya yang memiliki derajat rendah dalam menghindari ketidakpastian akan memiliki karakteristik yang berlawanan dengan orangorang yang memiliki derajat tinggi dalam menghindari ketidakpastian.

Dimensi maskulinitas-feminitas (Hofstede dalam Ting-Toomey, 1999:72) terkait dengan masyarakat yang dengan jelas membedakan karakteristik peran jender. Karakteristik seperti laki-laki lebih asertif, keras, dan memiliki fokus pada keberhasilan material, sementara perempuan yang cenderung rendah hati, lembut, dan berfokus pada kualitas hidup. Hofstede (1994:81) dalam konteks organisasi mengemukakan bahwa pada kutub maskulin, terdapat kesempatan untuk meraih pendapatan yang tinggi, pengakuan layak yang berkaitan dengan prestasi, kemajuan menuju tataran pekerjaan yang lebih tinggi, serta memiliki tantangan dalam pekerjaan. Sementara itu pada kutub feminin terdapat relasi kerja yang baik, kerjasama yang baik, dan keamanan dalam melakukan pekerjaan. Suatu hal lagi yang menjadi pembeda antara budaya maskulin dan feminin adalah pada cara atau proses peranan jender didistribusikan dalam suatu kelompok budaya. Para anggota budaya maskulin akan berorientasi pada ambisi, benda atau 
materi, kekuasaan, dan ketegasan, sementara para anggota budaya feminin akan memberi nilai yang tinggi pada kualitas hidup, pelayanan, perhatian pada orang lain di dalam kelompok, dan pemeliharaan hubungan.

\section{Pola-pola Parsons}

Dimensi pola-pola Parsons berbentuk dikotomi situasi. Satu sisi dapat dipilih oleh seorang pelaku komunikasi dengan mempertimbangkan konteks situasinya. Pola ini terdiri dari afektivitas-netralitas afektif, universalisme-partikularisme, ketersebaran-keterkhususan, askripsiprestasi, orientasi instrumental-ekspresif (Gudykunst dan Kim, 1997:78).

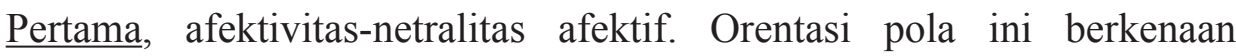
dengan sifat kepuasan yang dicari oleh manusia. Sisi afektivitas menjadi posisi dari orang yang mencari kepuasan segera dari situasi yang ada. Kedua, universalisme-partikularisme. Orientasi universalistik berfokus pada kategorisasi orang atau obyek dalam konteks referensi universal, sedangkan orientasi partikularistik berfokus pada kategorisasi orang atau obyek secara spesifik. Ketiga, ketersebaran-keterkhususan. Orientasi ini berfokus pada cara orang memberi respon pada orang lain. Dengan orientasi ketersebaran, respon holistik akan diberikan seseorang kepada orang lain, sedangkan orientasi keterkhususan ditampakkan seseorang dengan memberi respon terhadap orang lain dalam cara yang khusus Keempat, askripsi-prestasi. Orientasi askripsi dari seseorang akan tampak ketika orang tersebut memandang orang lain. Dengan orientasi askriptif, pandangan seseorang akan bertolak pada prediksi sosiokultural, yakni dalam kerangka keanggotaan orang lain di dalam kelompoknya, seperti jender, umur, ras, etnik, kasta, dan sebagainya. Sementara orang dengan orientasi prestasi akan mendasarkan prediksi dalam kerangka prestasi yang dapat diraih orang lain. Kelima, orientasi instrumental-ekspresif. Orientasi instrumental ditampakkan oleh orang dalam interaksinya dengan orang lain jika interaksi itu merupakan sarana untuk mencapai tujuan lainnya, sedangkan orientasi ekspresif akan tampak pada orang yang interaksinya dengan orang lain merupakan tujuannya.

\section{Keketatan Struktural}


Keketatan struktural merupakan dimensi yang berfokus pada norma, aturan, dan batasan yang berlaku pada anggota suatu komunitas. Budaya yang longgar hanya menerapkan sedikit peraturan dan batasan atas perilaku, sementara di dalam budaya yang ketat aturan dan batasan perilaku, norma dan aturan budaya cenderung jelas dan harus ditaati. Dalam budaya ketat, jika ada anggota komunitas yang melanggar norma dan aturan budaya dikenakan sanksi. Sebaliknya dalam komunitas budaya longgar, para anggota yang melanggarnya tidak akan dikenai sanksi sekeras pada budaya ketat (Gudykunst dan Kim, 1997:81).

\section{HASIL PENELITIAN}

\section{Deskripsi Budaya Perusahaan Inti}

Standarisasi tenaga kerja tingkat struktural PT Pagilaran berstandar pendidikan cukup tinggi dan semakin tinggi jabatan seseorang, ada kecenderungan semakin tinggi pula tingkat pendidikannya. Di tingkat pekerja produksi dan kebun, tingkat pendidikan para mandor pada umumnya STM dan SD. Komunitas perusahaan inti menanamkan nilai keteraturan kerja, disiplin, dan efisiensi pada semua karyawan. Pada tingkat produksi, standarisasi dilihat melalui dua hal, yaitu tuntutan standar kualitas bahan baku dan standar target tahunan. Adanya standar baku teh dimaksudkan agar secara ekonomis menguntungkan perusahaan. Pemahaman tentang target diterapkan di bagian produksi, khususnya mandor. Posisi mandor penting karena sebagai agen yang menjembatani perusahaan dengan petani, khususnya dalam penjualan pucuk teh.

Nilai ekonomi dijadikan tolok ukur keberhasilan anggota komunitas perusahaan inti, baik sebagai pekerja maupun anggota masyarakat. Ada kecenderungan orang perusahaan berorientasi ke masa depan. Artinya, ada persiapan untuk hidup ke depan, seperti menabung. Dalam dimensi budaya Hofstede, relasi kuasa merupakan simbol maskulinitas dari komunitas perusahaan inti. Adanya hubungan struktural yang sistemik dalam perusahaan inti menyebabkan munculnya relasi kuasa dalam komunitas perusahaan yang menjadi semacam sistem kontrol dalam relasi organisasi.

Meskipun berasal dari warga setempat, namun perusahaan 


\section{Jurnal}

memberlakukan standar pendidikan cukup bagi mandor. Namun dalam teknik berkomunikasi, perusahaan inti tidak pernah membekali mandor dengan kursus atau pelatihan. Hal penting dalam relasi perusahaan inti dengan petani adalah menjaga kesinambungan. Dari struktur organisasi, mandor berhubungan langsung dan berkomunikasi dengan petani plasma, sedangkan aktor perusahaan inti yang menempati posisi manajerial jarang berhubungan dengan petani plasma.

Mandor memiliki posisi berbeda dengan anggota masyarakat. Relasi mandor dengan masyarakat penting karena relasi menentukan kuantitas pucuk teh. Hubungan buruk antara mandor dan petani menyebabkan setoran pucuk teh berkurang, sehingga pabrik mengalami kerugian. Dengan menempatkan mandor sebagai "key person" petani akan selalu loyal kepada perusahaan inti. Perusahaan inti menganggap bahwa untuk berkomunikasi dengan petani dibutuhkan strategi tertentu. Perusahaan inti memberi kepercayaan sepenuhnya kepada mandor melakukan strategi komunikasi ini. Posisi mandor tepat untuk menjembatani komunikasi keduanya, karena mandor adalah petani setempat. Mandor mengetahui kebiasaan, adat, dan tradisi setempat sehingga mudah melebur dalam kehidupan sosial masyarakat.

\section{Perilaku Komunikasi Perusahaan Inti}

Komunitas perusahaan inti cenderung menggunakan komunikator dengan orientasi organisasi untuk menyampaikan pesan penyuluhan. Untuk komunikator penyuluhan, diperlukan mandor atau petugas lapangan yang berpendidikan, memiliki kemampuan membimbing petani dan mengelola anak buah, sehingga yang ditekankan adalah kompetensi dalam pekerjaan, aspek sosio-kultural mandor bukan pertimbangan utama.

Komunitas perusahaan inti cenderung menyampaikan pesan yang berorientasi organisasi, yaitu bisnis kemitraan. Kepada mandor selalu ditekankan agar memenuhi target produksi dengan tetap memahami realitas kondisi lahan petani yang terbatas. Sebagai pihak yang bermitra dengan petani kecil ia menyadari bahwa meskipun berbisnis, namun dalam kondisi kemitraan maka target harus dibuat lebih realistis. Hal ini karena konsep bisnis kemitraan tidak semata bertujuan meraih keuntungan, namun ada orientasi membina petani. Oleh karena itu mandor perlu memiliki empati terhadap keterbatasan petani dalam aspek dana untuk produksi serta 
kebutuhan petani akan uang tunai.

Dalam penyampaian pesan, perusahaan inti cenderung berkomunikasi dalam konteks rendah (low context) yang memiliki muatan informasi secara eksplisit berada dalam pesan yang disampaikan. Pesan berkonteks rendah disampaikan untuk informasi yang berkaitan dengan tugas. Perilaku komunikasi menunjukkan adanya orientasi verbal, yaitu pesan disampaikan dalam simbol verbal, berupa kata bermuatan pesan jelas. Bahasa verbal relatif tidak memiliki kerumitan makna, sehingga sesuai prinsip efektif-efisien untuk menyampaikan pesan. Perusahaan inti memiliki gaya komunikasi langsung ketika berbicara dengan petani dalam konteks tugas.

\section{Deskripsi tentang Budaya Petani Plasma}

Budaya petani yang utama adalah budaya subsisten. Petani terutama mengusahakan tanman pangan untuk kebutuhan diri, keluarga dan komunitasnya. Dalam penggunaan teknologi, selain sederhana, teknologi itu juga nonindustri. Mereka juga memiliki pertalian yang kuat dengan kondisi ekologis. Pada mulanya usaha tani tersebut tidak dilakukan dalam kerangka pengusaha pertanian, namun dengan adanya program PIR, petani mulai belajar kegiatan bisnis untuk meraih keuntungan ekonomis di samping untuk mengelola rumah tangga.

Petani juga berbudaya kolektivistik. Budaya kebersamaan di desa tempat komunitas petani plasma tinggal, masih terasa kental. Perasaan senasib sepenanggungan, satu lokalitas, dan hubungan sosial yang terjalin selama bertahun-tahun karena kedekatan tempat tinggal memunculkan adanya jalinan pertemanan, bahkan perasaan persaudaraan yang kuat.

Femininitas merupakan simbolisasi komunitas petani plasma. Komunitas petani plasma adalah komunitas petani Jawa yang mempunyai dasar moral orang Jawa dengan sifatnya yang utama untuk selalu menciptakan hidup yang selaras, sehingga keselarasan dalam masyarakat akan selalu dipelihara. Keselarasan hidup yang selalu dijaga ini dapat menjamin kehidupan yang baik bagi setiap petani, karena keselarasan tersebut dapat membawa pada ketentraman batin dan keseimbangan. Mereka yang bersifat buruk adalah yang memiliki masalah dalam hidupnya, yakni karena hidup yang tidak selaras, sehingga tak dapat hidup tenang. 
Ketentraman dan keselarasan tersebut juga terletak dalam relasi antarindividu dalam masyarakat. Sebagai bagian dari masyarakat, mereka harus tolong-menolong, bermusayawarah, rukun, dan andap asor dalam pergaulan. Selain dalam pergaulan antarmanusia, juga bagaimana petani membangun keseimbangan dalam relasi mereka dengan alam, sebagaimana kebiasaan petani untuk selalu mengadakan tradisi slametan legenanan. Sifat komunitas petani plasma tersebut merupakan simbol dari sifat yang selalu menjaga nature (alam) atau juga bisa diistilahkan sebagai sifat feminin, yaitu selalu dibedakan dan bahkan dilawankan dengan culture atau masculine yang cenderung mengeksplorasi dan merusak alam.

Petani plasma juga memiliki ciri mobilitas ke luar yang rendah. Umumnya petani jarang bepergian ke kota atau daerah lain di luar wilayah desanya. Mobilitas ke luar yang rendah mengakibatkan orientasi kehidupan petani plasma tidak seperti halnya para pekerja dan karyawan di PT Pagilaran yang berorientasi ke masa depan, melainkan petani umumnya berpikir untuk kecukupan hidup hari ini atau jangka pendek.

\section{Perilaku Komunikasi Petani Plasma}

Komunitas petani plasma pada dasarnya menyukai komunikator dengan orientasi lokal untuk menyampaikan pesan penyuluhan. Mandor yang bertugas di daerah ini merupakan mandor yang bukan berasal dari komunitas setempat. Dari keadaan tersebut dapat dikemukakan bahwa pada dasarnya, petani memiliki kecenderungan menyukai orang lokal sebagai sumber pesan. Oleh karena sumber pesan dalam penyuluhan adalah mandor, maka mandor yang berasal dari komunitas lokal dipandang oleh petani sebagai sumber pesan yang paling sesuai. Hal ini karena mandor lokal dapat mengerti slah (kemauan) petani. Selain itu, mandor lokal dipandang dapat memahami kebiasaan petani memperlakukan orang lain dengan tata cara lokal, misalnya tata cara dalam menghormati orang yang lebih tua.

Komunitas petani plasma cenderung menyampaikan pesan yang berorientasi pada hubungan atau kelompok. Dari beberapa informasi dapat disimpulkan bahwa orientasi isi pesan petani plasma yang disampaikan kepada perusahaan inti adalah di seputar kepentingannya untuk komunitasnya. Kepentingan itu seperti permohonan bantuan kendaraan untuk pembangunan jalan dan melaksanakan kegiatan pengajian bersama. 
Selain itu, juga untuk kepentingan memenuhi kewajibannya sebagai anggota komunitas, seperti menyumbang untuk acara yang berkaitan dengan tradisi komunitasnya.

Dalam penyampaian pesan, komunitas petani plasma ada kecenderungan berkomunikasi dalam konteks rendah dan dalam konteks tinggi. Seorang informan dengan lugas menyatakan bahwa yang penting dia menerima uang dari produksi pucuk tehnya. Sementara masalah perjanjian kontrak dia tidak pahami. Informan lain menyatakan bahwa petani pada saat belum menerima bayaran uang pucuk akan dengan lugas menanyakan apakah uang pucuk akan dibayarkan. Sementara itu informan lainnya menanyakan dengan pesan berkonteks rendah yang jelas maknanya bahwa ia membutuhkan tenaga kerja. Dari informan ini tampak bahwa ia meminta mandor yang bertugas di desanya untuk mengunjungi petani. Oleh karena ia selain sebagai petani tetapi juga bekerja di pabrik, maka ia perlu menjaga hubungannya dengan mandor. Untuk itu pesan disampaikan dalam konteks tinggi yang artinya bahwa kata tilik yang artinya berkunjung sesungguhnya memiliki makna lain, yaitu agar mandor memenuhi tugas membimbing petani di desanya.

Dua informasi tersebut dapat dimaknai adanya orientasi non-verbal petani saat tidak menyetujui realitas yang terjadi dalam relasi kemitraan. Pada saat tidak setuju, ada kecenderungan untuk menggunakan simbol non-verbal, seperti membabat tanaman teh atau mengganti tanaman tehnya dengan tanaman yang lain sebagai sikapnya terhadap harga pucuk teh yang tidak kunjung membaik. Dalam gaya penyampaian pesannya, komunitas petani plasma pada dasarnya memiliki gaya komunikasi tidak langsung. Dari situ dapat disimpulkan bahwa petani dalam konteks srawung, petani biasa berbicara apa saja tanpa tujuan, namun dari pembicaraan itu dapat muncul manfaat yang dapat diambil. Sebagai contoh mendapat manfaat memperoleh pekerjaan. Jadi mereka biasa membicarakan banyak topik sebelum ditemukan topik yang lebih penting seperti mendapat pekerjaan. Komunitas petani plasma cenderung memilih saluran komunikasi interpersonal yang informal dan memiliki kemampuan untuk mengembangkan hubungan, sehingga dapat dikatakan bahwa kecenderungan ini bermula dari karakteristik relasinya yang ekspresif. Saluran seperti ini dapat dilihat dalam bentuk srawung. 
Wahana adaptasi komunikasi Perusahaan Inti terhadap petani plasmanya adalah dengan memanfaatkan budaya Jawa yang serba "rikuh" sebagai upaya untuk membina relasi kuasa yang pada akhirnya akan menguntungkan perusahaan. Pemberian jabatan di perusahaan pada anggota masyarakat setempat melalui kelompok petani plasma secara tidak langsung diyakini oleh perusahaan sebagai upaya meredam konflik.

Budaya 'ngaruhke' dikenal sebagai bentuk relasi sosial yang umum terjadi pada masyarakat Jawa. Ngaruhke berarti berkunjung untuk mengungkapkan perasaan. Di sini komunikasi yang terjadi lebih banyak bersifat ekspresif karena pelaku komunikasi hanya menanyakan kabar, atau bersimpati pada suatu keadaan tertentu. Baik dalam konteks suasana bahagia maupun suasana duka. Turut hadir dan menyumbang pada acara hajatan di desa adalah salah satu bentuk 'ngaruhke'. Demikian juga bila datang pada acara kematian. Para aktor di komunitas perusahaan, terutama yang di bagian kebun (seperti Kepala Unit), amat paham dengan hal ini.

Di sisi lain, pihak perusahaan inti juga menyadari bahwa mandor punya peran yang cukup besar dalam budaya "ngaruhke", karena mereka berasal dari masyarakat setempat yang diangkat. Mereka juga sering diundang dalam berbagai kesempatan. Agak berbeda dengan pihak manajerial yang tidak selalu diundang dalam setiap acara di desa.

Pada dasarnya perusahaan inti memahami bahwa terdapat perbedaan yang cukup besar antara perusahaan inti dan petani plasma. Mandor, sebagai ujung tombak perusahaan inti dalam membangun relasi dengan petani menyadari arti penting komunikasi untuk menyelesaikan masalah. Bahkan mandor juga menyediakan jadwal khusus untuk bertemu dengan petani di wilayah kerja mereka masing-masing. Pihak perusahaan inti juga menyadari bahwa menjalin relasi dengan masyarakat setempat menjadi hal yang penting dilakukan untuk menjaga kesinambungan antara pabrik dan petani. Karenanya ia "merelakan" petugas lapangan atau mandor kerap beranjangsana ke desa dan berinteraksi dengan masyarakat desa secara informal. Istilah yang kerap digunakan adalah 'wedangan' atau minumminum (seperti teh atau kopi) sambil mengobrol. Langkah ini tampaknya menimbulkan rasa iri di sebagian pekerja pabrik karena mereka dianggap tidak bekerja.

Dalam relasi sosialnya dengan komunitas petani plasma, perusahaan 
inti cenderung beradaptasi dengan tujuan untuk kepentingan industri tehnya. Selain itu perusahaan inti juga merasa perlu mengembangkan komunikasi yang sesuai dengan budaya komunitas petani plasmanya dalam kerangka kepentingan industri pula. Pendekatan adaptasi melalui pengembangan komunikasi yang sesuai dengan budaya komunitas petani plasma, tampak memberikan hasil, yaitu terciptanya hubungan perusahaan inti dengan komunitas petani plasma yang berujung pada terpenuhinya kepentingan bisnis teh PT Pagilaran.

Sementara itu adaptasi dalam strategi konvergensi dilakukan dengan pengangkatan mandor lokal. Hal ini didasari pengalaman bahwa mandor lokal terbukti lebih berhasil dalam mendekati petani. Meskipun demikian, ada catatan seorang informan, yang menyatakan bahwa mandor lokalpun ada yang bermasalah dengan petaninya, yaitu ketika tidak bisa memahami kemauan (slahe) petani. Oleh karena itu yang penting kemudian adalah bagaimana memahami kemauan petani. Namun orang lokal tampak lebih diutamakan dalam pengangkatan mandor. Strategi konvergensi dilakukan pula oleh komunitas perusahaan inti ketika menghadapi keluhan petani. Pernyataan yang bermakna sepakat atas kondisi sulitnya kehidupan petani dapat menunjukkan bahwa perusahan memiliki empati terhadap petani. Dari catatan pengalaman informan, tampak bahwa adaptasi yang dilakukan oleh komunitas perusahaan inti dalam gaya penyampaian adalah dengan menggunakan cara bicara berputar-putar untuk pesan yang sensitif yang bisa menggangu relasi antara mandor dan petani. Selain itu juga menggunakan gaya penyampaian pesan berkonteks tinggi untuk mengubah perilaku petani. Sementara itu, dalam elemen saluran, adaptasi konvergensi yang dilakukan oleh perusahaan inti adalah dengan menggunakan saluran interpersonal yang lebih informal. Dari catatan informan dapat dikemukakan bahwa saluran interpersona dipandang lebih efektif dalam memberikan bimbingan kepada petani. Dalam strategi divergensi, adaptasi dilakukan ketika petani menunjukkan perilaku yang tidak sesuai dengan aturan-aturan atau tatacara perusahaan. Para mandor pada umumnya segera menunjukkan identitas mereka dengan menegur petani agar melakukan pekerjaan sesuai dengan tuntutan perusahaan. 
Dari paparan tersebut dapat dikemukakan beberapa hal sebagai kesimpulan sebagai berikut, pada hakekatnya ada perbedaan budaya komunitas perusahaan inti dan petani plasma. Budaya komunitas perusahaan inti cenderung berorientasi kepentingan ekonomi (komersial), sedang budaya petani cenderung berorientasi kepentingan kelompok dan pemeliharaan hubungan. Seiring proses adaptasi, kedua komunitas cenderung berbudaya sama. Keduanya berorientasi kepentingan kapital. Adaptasi dilakukan oleh komunitas perusahaan inti dengan strategi divergensi, yaitu penyesuaian dengan tetap mempertahankan budayanya sendiri dan menunjukkan budayanya kepada budaya petani. Budaya yang sama dapat dilihat dari dua sisi. Dari sisi perusahaan inti, budaya yang sama adalah karena pada dasarnya orang-orang perusahaan inti berasal dari budaya yang sama dengan petani. Selain itu adanya pengaruh lingkungan karena pabrik berada di wilayah petani. Dari sisi petani, budaya yang sama adalah karena adanya hasil dari adaptasi budaya. Budaya yang berbeda antara komunitas perusahaan inti dan komunitas petani plasmaadalah karena adanya aturan-aturan normatif yang harus dipegang oleh orang-orang dari perusahaan inti. Selain karena adanya perbedaan tingkat pendidikan dan wawasan yang dimiliki. Budaya berimplikasi pada perilaku komunikasi. Pada komunitas perusahaan inti, budaya yang berorientasi pada perolehan kapital ini berimplikasi pada perilaku komunikasi yang pesannya berfokus pada kepentingan bisnis, sumber informasinya haruslah memenuhi standar kemampuan tertentu, low context, verbal, to the point, dan mengandalkan kelompok-kelompok formal. Adapun perilaku komunikasi pada komunitas petani lebih beorientasi pada kepentingan lokal, pemeliharaan hubungan dan kelompok, high context, menggunakan simbol non-verbal dan berputarputar, tidak langsung pada inti pembicaraan, serta menggunakan saluran informal dan interpersonal; (6) Perbedaan komunikasi pada dua komunitas ini menghambat proses pencapaian tujuan organisasi, oleh karena itu perusahaan berinisiatif melakukan adaptasi dengan menggunakan strategi konvergensi. Perilaku komunikasi komunitas perusahaan inti diubah dan disamakan dengan perilaku komunikasi komunitas petani; (7) Inisiatif komunikasi perusahaan inti untuk melakukan adaptasi perilaku komunikasi didasarkan pada ketergantungan komunitas ini pada komunitas petani sebagai pemilik lahan; (8) Upaya konvergensi pada tataran perilaku komunikasi semata-mata untuk dapat mengubah budaya komunitas petani 
menjadi sama dengan budaya komunitas perusahaan, yang pada akhirnya, dapat mengarahkan pada relasi kemitraan dengan petani plasma, yang merupakan faktor kunci keberhasilan perusahaan inti

Dari hasil penelitian dapat pula diambil kesimpulan bahwa cakupan teoritik dari teori antarbudaya perlu diperluas dengan mempertimbangkan aspek strategi untuk mencapai tujuan adaptasi. Dengan demikian secara nyata dapat dimunculkan tipe strateginya, konvergensi atau divergensi. Hal ini sangat signifikan dalam konteks kontribusi di tataran praksis yang berupa kompetensi komunikasi. Kompetensi komunikasi yang diperlukan dalam suatu upaya pembangunan yang melibatkan pihak-pihak berbeda budaya.

\section{DAFTAR PUSTAKA}

Boeke, J.H. 1983. Prakapitalisme di Asia. Sinar Harapan. Jakarta.

Diaz, May N. 1967. "Economic Relations in Peasant Sociey" dalam Jack M. Potter, May N. Diaz \& George M. Foster (eds). Peasant Society: A Reader. Little, Brown and Co. Boston.

Ellingsworth, Huber W. 1988. "A Theory of Adaptation in Intercultural Dyads" dalam Young Yun Kim \& William B. Gudykunst (eds). Theories in Intercultural Communication. Sage Publications. Newbury Park.

Foster, George M. 1967. "What is Peasant" dalam Jack M. Potter, May N. Diaz \& George M. Foster (eds). Peasant Society: A Reader. Little, Brown \& Co. Boston.

Gudykunst, William B. 2002. "Intercultural Communication Theories" dalam William B. Gudykunst \& Bella Mody (eds). Handbook of International and Intercultural Communication. $2^{\text {nd }}$ Ed. Sage Publications. California.

Gudykunst, William B. \& Carmen M. Lee. 2002. "Cross-Cultural Communication Theories" dalam William B. Gudykunst \& Bella Mody (eds). Handbook of International and Intercultural Communication. $2^{\text {nd }}$ Ed. Sage Publications. California.

Gudykunst, William B. \& Young Yun Kim. 1997. Communicating With Strangers: An Approach to Intercultural Communication. $3^{\text {rd }}$ Ed. McGraw-Hill. Boston. 
Hofstede, Geert. 1994. Culture and Organizations. HarperCollinsBusiness. Hammersmith.

Martodireso, Sudadi \& Widodo Agus Suryanto. 2002. Agribisnis Kemitraan Usaha Bersama: Upaya Peningkatan Kesejahteraan Petani. Kanisius. Yogyakarta.

Pambudy, Rachmat, dkk. 2003. Bisnis dan Kewirausahaan dalam Sistem Agribisnis. Pustaka Wirausaha Muda. Bogor.

Scott, James C. 1981. Moral Ekonomi Petani: Pergolakan dan Subsistensi di Asia Tenggara. LP3ES. Jakarta.

Slamet, Margono. 2003. "Meningkatkan Partisipasi Masyarakat dalam Pembangunan Pedesaan" dalam Ida Yustina \& Adjat Sudrajat (eds). Membentuk Pola Perilaku Manusia Pembangunan. IPB Press. Bogor.

Soekartawi. 2003. Agribisnis: Teori \& Aplikasinya. Raja Grafindo Persada. Jakarta.

Sumardjo, Joko Sulaksana \& Wahyu Aris Darmono. 2004. Teori dan Praktik Kemitraan Agribisnis. Penebar Swadaya. Jakarta.

Suriasumantri, S. Jujun. 2000. Filsafat Ilmu: Sebuah Pengantar Populer. Pustaka Sinar Harapan. Jakarta.

Suroso. 1999. "Pengalaman Penerapan Kemitraan Usaha di Sektor Perkebunan" dalam Haryono Semangun, Sri Widodo, Mas Soedjono, Hardiman, dan Djoko Muljanto (eds). Kemitraan Usaha Perkebunan. Fakultas Pertanian UGM. Yogyakarta.

Ting-Toomey, Stella. 1999. Communicating Across Cultures. The Guilford Press. New York.

Triandis, Hary C. 1995. Individualism \& Collectivism. Westview Press, Inc. Colorado.

Weitz, Raanan. 1971. From Peasant to Farmer: A Revolutionary Strategy for Development. Columbia University Press. New York.

Wolf, Eric R. 1983. Petani: Suatu Tinjauan Antropologis. Rajawali Jakarta. 